\title{
Expression of concern: necrotizing fasciitis, literature review of contemporary strategies for diagnosing and management with three case reports: torso, abdominal wall, upper and lower limbs
}

Fausto Catena and Frederick Moore, Editors-in-Chief, World Journal of Emergency Surgery

\section{Comment on}

Zdravko Roje, Željka Roje, Dario Matić, Davor Librenjak, Stjepan Dokuzović and Josip Varvodić. Necrotizing fasciitis: literature review of contemporary strategies for diagnosing and management with three case reports: torso, abdominal wall, upper and lower limbs. World Journal of Emergency Surgery 2011 6:46. doi:10.1186/1749-7922-6-46. URL http://www.wjes.org/content/6/1/46.

The Editors-in-Chief would like to alert readers that the accuracy of details described in Case III (56 year old male) of this article [1] have been questioned by a reader. Unfortunately, for legal reasons, the authors' institution has not been able to confirm or refute whether the events reported about the case are accurate. Consequently, readers are advised to interpret the details of Case III with caution.

Received: 26 July 2012 Accepted: 2 August 2012

Published: 18 October 2012

\section{References}

1. Roje J, et al: Necrotizing fasciitis: literature review of contemporary strategies for diagnosing and management with three case reports: torso, abdominal wall, upper and lower limbs. World Journal of Emergency Surgery 2011, 6:46.

Submit your next manuscript to BioMed Central and take full advantage of:

- Convenient online submission

- Thorough peer review

- No space constraints or color figure charges

- Immediate publication on acceptance

- Inclusion in PubMed, CAS, Scopus and Google Scholar

- Research which is freely available for redistribution

*Correspondence: faustocatena@gmail.com 